\title{
IX. On meteoric stones
}

\section{Rev. T. Drummond}

To cite this article: Rev. T. Drummond (1816) IX. On meteoric stones, Philosophical Magazine Series 1, 48:219, 28-28, DOI: 10.1080/14786441608637603

To link to this article: http://dx.doi.org/10.1080/14786441608637603

曲 Published online: 27 Jul 2009.

Submit your article to this journal $\widetilde{ }$

III Article views: 2

Q View related articles $\asymp$ 
hitherto been found to exist in human urinary concretions, at any rate, in the large proportion it seems to be in this; yet 1 have some faint recollection of having heard or read of the same thing thaving been noticed by Vauquelin (I believe). You must pardon me if I am incorrect.

Since I examined the above, I have received another portion; a more correct analysis of which I shall give you for insertion in your next number.

I remain, dear sir,
Very truly yours,
76, Drury Lane, July 13, 1816.

IX. On Meteoric Stones. By the Rev. T. Drummond.

\section{To Mr. Titloch.}

Sir, - U Uwilling to trespass on your pages by a long letter, I forbore to notice in my last, that it appears on the authority of Pliny, that metearic stones or aërolites were supposed to have fallen from the body of the sun; your pages record that sonve modern philosophers have imagined them to have been projected from the moon. I will not trouble you at this time with any arguments in support of an opinion, that they are generated in the regions between our earth and the nearest planets; but since I do not remember that any of your correspondents have noticed the circunstance, I wish to mention that the same author records a report that Anaxagoras Clazomenius had predicted the fall of a meteoric stone, and that the prediction was verified. [Lib. ii. c. 58.]

If, sir, we admit the report to have been correct, may we not infer that astronomical caleulations and a regard to planetary influences must have Jed the philosopher to deduce his inference?

If it be merely to gratify curiosity, I hope your readers in the different parts of the civilized world will transmit to yon an accurate statement of the precise time in which the phænomena occur in future. Our pride in modern science must be humbled by every indication of the attainments of the ancients, unless we can refute, or equal, or excel them.

$$
\text { Yours respectfully, }
$$

Norwich, Gray Friars' Priory,

T. DRUMMOND. Jily $6,1816$. 